\title{
Buffon, Jefferson and the theory of New World degeneracy
}

Lee Alan Dugatkin ${ }^{*}$ (D)

\begin{abstract}
In his magnum opus, Natural History: General and Particular, Count Buffon, one of the leading natural historians of the 18th century, argued that all life in the New World, particularly North America, was degenerate-weaker, smaller and feebler-than life in the Old World. This work tapped into pre-existing fears in Europe that America might emerge as a rival on the world stage, and so both the leaders, like Fredrick the Great, and the people of Europe (Natural History was a best seller), embraced what became known as the theory of New World degeneracy. In the fledgling United States, Thomas Jefferson and others took the lead to debunk this theory. Despite Jefferson's refutation, the theory of degeneracy far outlived Buffon and Jefferson. It continued to be debated for nearly 100 years, in scientific, literary and political circles. Eventually the degeneracy argument died; but it did not die an easy death.
\end{abstract}

Keywords: New World degeneracy hypothesis, Count Buffon, Thomas Jefferson

\section{Introduction}

In the middle of the 18th century, the New World, and in particular, North America, was a mystery to the governments and people of Europe. It might very well be a place of endless resources, to which people could migrate, along with their money, to go off and lead better lives. And, for this very reason, the monarchs of Europe were worried. As were the people who would not have the opportunity to migrate, which was the vast majority of the population. It was in this environment that the world's leading natural historian, Georges-Louis LeClerc-better known by his title Count Buffon-introduced an idea which played directly into fears of the unknown, providing what was seen as a scientific justification of why migration to the New World would be a mistake.

Like many philosophes of the French Enlightenment Buffon was a driven man. At nineteen he graduated law school, but decided against a profession in law, as his eclectic interests had turned to mathematics. In 1733, he was inducted into the French Royal Academy of Sciences for his work on probability theory, centering on a game of chance called Franc-carreau. Seven years later, he

*Correspondence: Lee.Dugatkin@Louisville.Edu

Department of Biology, University of Louisville, Louisville, KY 40292, USA campaigned for, and received, the most prestigious position for a natural philosopher/scientist in Europe. Based on his reputation as a well-rounded thinker, his election to the Royal Society of London, and a bit of botanical work he had done at a huge forest his well-to-do family owned, Buffon was appointed curator of the King's Cabinet of Natural History (the Cabinet du Roi) (Roger 1997).

In his role as curator, Buffon decided that he would write the definitive encyclopedia of natural history: what, over time, became Natural History: General and Particular (Histoire Naturelle, Generale et Particular). From 1749 until his death in 1788, Buffon would publish 36 volumes of Natural History (Buffon 1749-1788). These volumes, in sum, approached 6000 pages, and included hundreds of stunningly beautiful sketches drawn by Louis-Jean-Marie Daubenton. Natural History was a huge success, and was translated into English, Dutch and German. It was also the talk of the Paris salons, and Buffon quickly became a national hero, on the scale of Voltaire and Rousseau, with Louis XVI having his statue cast and placed in front of the Royal Gardens (where it remains to this day).

In Natural History, the most sweeping encyclopedia of natural history ever written, Buffon claimed that all life in the colonies/fledgling United States was small, weak and feeble compared to life in the Old World-that life 
in America was degenerate. In Volumes 9 and 14 Buffon introduces the reader to what would be dubbed the New World degeneracy hypothesis (though Buffon uses the word degeneracy on numerous occasions, he never uses the exact phrase "New World degeneracy hypothesis" himself). Compared to the Old World, animal life, Buffon proposed, was "shriveled and diminished" 1 in the New World (particularly North America). A few of the many examples that the Count provides include:

"Animated nature, therefore is less active, less varied, and even less vigorous, for by the enumeration of the American animals we shall perceive, that not only the number of species is smaller, but that in general, they are inferior in size to those of the old continent."

"The wolf and fox are common to both continents... but all of them are smaller than those of Europe, which is the case with every animal, whether native or transported."

"... all the animals which have been transported from Europe having become less, and also those common to both continents being much smaller in America than those of Europe."

Dogs of the New World were "absolutely dumb", "perfectly mute", and in cold regions "they have decreased in size.... Thus, they have degenerated."

Buffon himself had never been to North America, and instead based his claims on specimens in the King's Cabinet of Natural History, prior published material on North America, accounts from travelers who had been to the New World, and a small menagerie he kept at his summer home, which included some New World and Old World animals.

In Volumes 9 and 14 of Natural History Buffon makes four claims about the degenerate nature of North American animals, and in general, New World animals:

1. Animals found in both the New World and the Old World are smaller, weaker and feebler-degeneratein the New World.

2. Animals found only in the New World are degenerate compared to those found only in the Old World.

\footnotetext{
${ }^{1}$ Natural History, IX, 103-104.

${ }^{2}$ Natural History, IX, 86.

${ }^{3}$ Natural History, IX, 100.

${ }^{4}$ Natural History, IX, 101-102.

${ }^{5}$ Natural History, IX, 75-76.
}

3. Fewer species are present the New World.

4. Any attempt to domesticate animals (e.g., sheep, cows, dogs) in the New World would lead to degeneration of that species.

Buffon also had a theory for why degeneracy occurred in New World animals, hypothesizing that the New World was colder and more humid, and that this combination led to degeneracy. In the mid-late 1700s, these were not fringe ideas: for example, the leading theory for disease at the time was that it was created and spread through the "miasma" that rose off bodies of stagnant water. And it was not chance that Buffon thought that cold and humidity were the norm for North America. Much of the information he had was from French travelers that had been there and then returned to Paris. Such travelers often spent their time trapping in Canada and the northern United States, where it was extremely cold during the winter, or in the humid French-owned province that would become Louisiana.

It was not just the animals of North American that were degenerate, so too were the indigenous people, exposed to the dangerous combination of cold and humidity. Native Americans were, Buffon pronounced:

"... a kind of weak automaton, incapable of improving or seconding her (Nature's) intentions. She treated them rather like a stepmother than a parent, by refusing them the invigorating sentiment of love, and the strong desire of multiplying their species... In the savage, the organs of generation are small and feeble. He has no hair, no beard, no ardour for the female... He has no vivacity, no activity of mind... They have been refused the most precious spark of Nature's fire: They have no ardour for women, and, of course, no love to mankind... Their love to parents and children is extremely weak. The bonds of the most intimate of all societies, that of the same family, are feeble; and one family has no attachment to another... Their heart is frozen, their society cold, and their empire cruel..."

While there is no evidence that Buffon was politically motivated with his theory of New World degeneracy, or that he intended that his idea should feed into pre-existing fears of the New World, and its eventual place on the world stage, the idea did precisely that, providing what was seen as a scientific justification for not migrating to the New World.

Before continuing our discussion of New World Degeneracy, it is important to note that the term "degeneracy"

${ }^{6}$ Natural History, IX, 104-106. 
has a long, often checkered, history in science and mathematics. It has been used many times, and in many different ways in biology, physics and mathematics, referring to everything from mental characteristics and degenerative communication systems to the degeneracy (that is, redundancy) of the genetic code and degenerative distributions in mathematics. In this paper I use degeneracy strictly as Buffon applied the idea to natural history and the New World.

The theory of New World degeneracy was extraordinarily popular in Europe and was expanded by Abbe Cornelius de Pauw, who proposed that Europeans who migrated to the New World would also degenerate, as would their offspring (De Pauw 1768; Raynal 1772), and for the same reason that animals and Native Americans degenerated: the pernicious effects of cold and humidity. And in de Pauw's case, there is some evidence he meant for his ideas to have political ramifications and to be interpreted as the scientific basis not to migrate to the New World.

De Pauw was educated at the University of Gottingen, after which he accepted a clergy position in the Prussian district of Xanten. From then until his death in 1799, he led a secluded life that appears interrupted only by two visits to Frederick the Great, King of Prussia, at his palace at Potsdam. In late 1767, de Pauw met the king, who offered him a position as his "private reader". After just a few months, de Pauw missed the seclusion he enjoyed in Xanten, and returned to his parish. He spent some additional time with King Frederick in later years, but again returned to Xanten. His interactions with Frederick the Great, however, increased de Pauw's standing in Prussia and Europe in general, and his writings are sometimes referred to as being penned by Frederick the Great's "personal advisor" (Beyerhaus 1926; Church 1936).

In 1768, a year after he served as Fredrick's private reader, de Pauw published a short book called Philosophical Researches on the Americans (Recherches philosophiques sur les Américains), which was translated into German, Dutch and English and eventually went through eleven editions before the end of the eighteenth century (De Pauw 1768). In Philosophical Researches, de Pauw first summarized Buffon's ideas, using even more hyperbolic language than the Count: "The great humidity of the atmosphere, the prodigious quantity of stagnant waters, the noxious vapors, corrupt juices, and vitiated qualities of the plants... will account for that feebleness of complexion, that aversion from labour, and general unfitness for improvement of every kind, which prevented the Americans from emerging out of savage life"7 (de Pauw 1768). Buffon spoke only of the effects of degeneracy on

${ }^{7}$ de Pauw, 1768 animals and Native Americans, but de Pauw warned that degeneracy had, and would continue, to affect Creoles-a term used for Europeans born in America:

"The Europeans who pass into America degenerate, as do the animals: a proof that the climate is unfavorable to the improvement of either man or animal. The Creoles, descended from Europeans and born in America... have never produced a single book. This degradation of humanity must be imputed to the vitiated qualities of the air stagnated in their immense forests, and corrupted by noxious vapours from standing waters and uncultivated grounds."

The future held no hope for change on this front, de Pauw continued, for "the people of whom we are speaking will never rise above their present abject condition" (de Pauw 1768).

If Buffon had already laid out the basic idea of degeneracy in North America, why did de Pauw feel the need to write a book-long extension of this idea, emphasizing the effects on Creoles? The answer probably lay in the general fear that many Europeans had regarding the potential of the New World. The idea that Europeans could now emigrate and obtain vast tracts of land on the other side of the globe was not appealing to Old World monarchs, including Fredrick the Great. de Pauw may have written Philosophical Researches partly to ingratiate himself to Frederick (Echeverría 1957). Frederick had a strong anti-emigration policy when it came to North America. Indeed, he had established a special bureau in Hamburg whose primary function was to prevent emigration to the New World, and instead to attract potential newcomers to Prussia. After Frederick warmly welcomed de Pauw into his court, Philosophical Researches may have been a thank you of sorts from de Pauw to the king, providing him a natural history/natural philosophy justification for his North America anti-migration policy.

\section{The response from North America}

When the theory of New World degeneracy reached the shores of the Colonies/early United States, it was not well received (Gerbi 1973; Dugatkin 2009). In the next section, we will examine how Jefferson led the charge against this theory. But other Founding Fathers also commented on Buffon's ideas, albeit not nearly in the depth Jefferson did. John Adams called the idea of New World degeneracy "despicable dreams" (Adams 1787), and James Madison wrote Jefferson that measurements which he himself had taken on American weasels, and then compared to the weasel's Old World counterparts, showed how misguided Buffon was. His data, Madison wrote Jefferson, "certainly contradicts his (Buffon's) assertion that of the 
animals common to the two continents, those of the new are in every instance smaller than those of the old".

In Federalist Number 11, Alexander Hamilton noted that

"Men admired as profound philosophers have, in direct terms, attributed to her inhabitants a physical superiority, and have gravely asserted that all animals, and with them the human species, degenerate in America-that even dogs cease to bark after having breathed awhile in our atmosphere."

Hamilton's reply to such "profound philosophers" was that New World degeneracy ideas were "arrogant pretensions", and that "it belongs to us to vindicate the honor of the human race, and to teach that assuming brother", by which Hamilton meant Europe, "moderation"."

\section{Jefferson and degeneracy}

Many years later, when President Thomas Jefferson presented Meriwether Lewis the orders for his mission with William Clark, those orders were written by Jefferson himself, wherein he instructed Lewis and Clark, among other things, to measure:

"...the soil \& face of the country, its growth \& vegetable productions... the mineral productions of every kind... metals, limestone, pit coal, \& saltpeter; salines \& mineral waters...volcanic appearances... climate, as characterized by... the proportion of rainy, cloudy, E clear days, by lightning, hail, snow, ice, by the access $\mathcal{E}$ recess of frost, by the winds prevailing at different seasons, the dates at which particular plants put forth or lose their flower, or leaf, times of appearance of particular birds, reptiles or insects."

These orders were clearly written by a man who knew his natural history. But, Jefferson was more than interested in natural history-he was enamored with it. "There is not a sprig of grass", he wrote his daughter, "that shoots uninteresting to me."10 He wanted nothing more, he wrote his friend Pierre-Samuel DuPont, than to escape "the boisterous ocean of political passions", and return to his Monticello and study natural history. "Nature", Jefferson told Dupont, "intended me for the tranquil pursuits of science, rendering them my supreme delight." ${ }^{11}$

When Jefferson learned of Buffon's theory of New World degeneracy, he was outraged, and also somewhat

\footnotetext{
${ }_{8}^{8}$ Madison to Jefferson, December 4, 1786.

${ }^{9}$ Federalist, Number 11.

${ }^{10}$ Jefferson to Martha Jefferson Randolph, December 23, 1790.

11 Jefferson to Dupont, March 2, 1809.
}

surprised. Surprised because on all other issues, Jefferson thought Buffon one of the great minds of the Enlightenment, referring to him as a "celebrated Zoologist, who has added and is still adding, so many precious things to the treasures of science" (Jefferson 1785). He knew of many of Buffon's accomplishments in natural history, geography, anthropology and mathematics, and had great respect for the Count. But with respect to the theory of New World degeneracy, Jefferson was furious that the world's leading natural historian would make such sweeping, damning, claims about life on an entire continent. In addition, Jefferson was far from convinced that the data Buffon used to build his theory was reliable. Travelers' tales from Frenchmen who had been to the New World seemed to Jefferson a weak basis on which to generate such a theory:

"It does not appear that Messrs. de Buffon and D'Aubenton (who did the sketches) have measured, weighed, or seen those of America... and ... who were these travelers? Was natural history the object of their travels? Did they measure or weigh the animals they speak of? Or did they not judge of them by sight, or perhaps even from report only? Were they acquainted with the animals of their own country, with which they undertake to compare them? Have they not been so ignorant as often to mistake the species?" (Jefferson 1785).

Jefferson's refutation of the theory of degeneracy began with his Notes on the State of Virginia, a book that was, ostensibly, an overview of Jefferson's home state, where he served as governor from 1779 to 1781 . Yet, the longest chapter of the book, entitled "Production, mineral, vegetable and animal", was all about debunking the theory of New World degeneracy. In Notes, Jefferson writes:

"... the opinion of a writer (Buffon), the most learned too of all others in the science of animal history, that in the new world... that nature is less active, less energetic on one side of the globe than she is on the other. As if both sides were not warmed by the same genial sun; as if a soil of the same chemical composition, was less capable of elaboration into animal nutriment; as if the fruits and grains from that soil and sun, yielded a less rich chyle, gave less extension to the solids and fluids of the body, or produced sooner in the cartilages, membranes, and fibres, that rigidity which restrains all further extension, and terminates animal growth. The truth is, that a Pigmy (sic) and a Patagonian, a Mouse and a Mammoth, derive their dimensions from the same nutritive juices." (Jefferson 1785). 


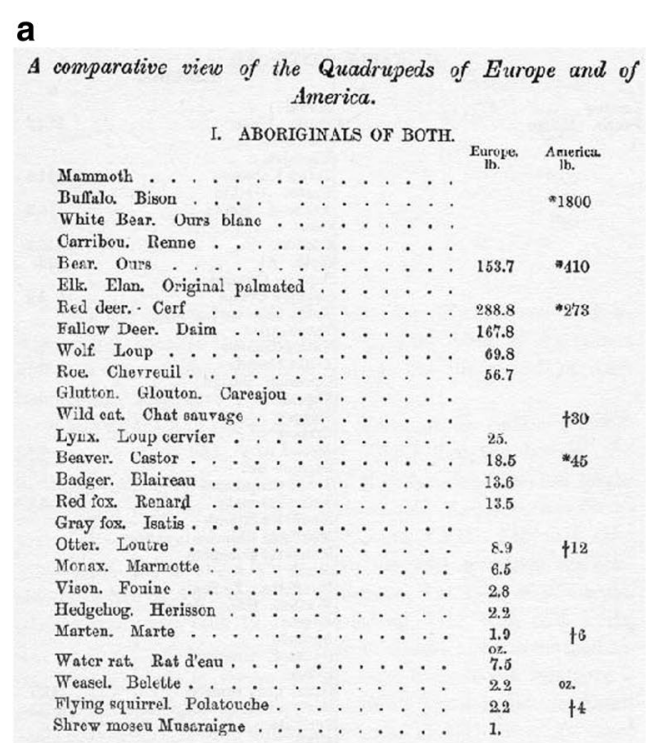

b

Fig. 1 Two of the tables Jefferson used as evidence against the theory of New World degeneracy. a Here Jefferson compares the size of (a small sample set of the) animals found in both the New World (in this case represented by America) and the Old World (represented by Europe), and finds no evidence that those in the latter are larger. $\mathbf{b}$ In this table Jefferson compares the size of animals found only in the New World and those found only in the Old World (represented by Europe). Again, he finds no evidence that those in the latter are larger

Jefferson admitted that climate might affect the size of animals, but argued there is no evidence that it actually does. "It is the uniform effect of one and the same cause, whether acting on this or that side of the globe", Jefferson wrote, and "it would be erring therefore against that rule of philosophy, which teaches us to ascribe like effects to like causes, should we impute this diminution of size in America to any imbecility or want of uniformity in the operations of nature" (Jefferson 1785).

Notes on the State of Virginia has four tables of data that Jefferson presents contra to Buffon's claims of degeneracy (Fig. 1). Notes was a popular book, but Jefferson understood that it was dry, and that to really make his point about degeneracy to the public, he would need to do something more. He settled on a plan: he would have one of his friends procure for him a very large moose, ideally, he wrote, one seven to ten feet tall, then he would have that moose stuffed and sent to Buffon, who would have no choice but to admit that life in America was not small, weak and feeble.

The hunt for that giant moose involved many of Jefferson's friends, but soon rested on his colleague, General John Sullivan. Sullivan had been a representative at the Second Continental Congress, and when Jefferson approached him about obtaining a moose to send to Buffon, he was Attorney General of New Hampshire. Still, Sullivan searched for the moose himself, and he also sent out orders to some of his colleagues to look for the perfect animal for Jefferson. Sullivan kept Jefferson apprised on the search, and Jefferson expressed his thanks for such updates: "The readiness with which you undertook to endeavor to get for me the skin, the skeleton and the horns of the moose", Jefferson wrote Sullivan, "emboldens me to renew my application to you for those objects, which would be an acquisition here, more precious than you can imagine." 12

In 1784, while the hunt for the moose was on, Jefferson was appointed minister plenipotentiary to France. When he arrived in Paris, he received an invitation to dine with the Count at Buffon's country residence. At the dinner, Jefferson told Buffon that the theory of New World degeneracy was simply wrong, and "that the (European) rein deer could walk under the belly of our moose". Buffon finally relented and agreed that he would "give up the question", if Jefferson could provide him with such a moose (Wiltse and Moser 1974). ${ }^{13}$

Sullivan continued to update Jefferson on his hunt for the moose, and in the winter of 1787, he told Jefferson that a team of a dozen men he had hired had gotten the perfect animal, and that:

"every engine was set at work to preserve the bones and cleanse them from the remaining flesh. And to preserve the skins with hair on, with the hoofs on

\footnotetext{
12 Jefferson to Sullivan, January 7, 1786.

13 Daniel Webster's recollection of Jefferson, edited by Wiltse, Volume 1, pp. 376-377.
} 
and bones of legs and thighs in skin without putrefaction...the skin (of the head) being whole and well dressed (sic) it may be drawn on at pleasure." (Sullivan to Jefferson, April 16, 1787)

The stuffed moose, after a number of false starts, finally arrived in Paris in early October 1787. Jefferson wanted to deliver it to Buffon himself, in person, but Buffon was too ill to receive visitors. Buffon's assistant acknowledged receipt of the moose, and Jefferson noted in his diary that the moose had "convinced Mr. Buffon. He promised in his next volume to set these things right", that is, that Buffon would retract the theory of New World degeneracy in the next volume of Natural History: General and Particular (Wiltse and Moser 1974). ${ }^{14}$

But there was to be no such next volume of Natural History. Soon after he received the moose, Buffon died. There was no retraction. The theory of New World degeneracy can still be found in volumes 9 and 14 of Natural History: General and Particular. Jefferson knew that Buffon knew he was wrong, and that gave him some solace. But he feared that the theory of New World degeneracy would live on after the Count and weave its tentacles into the brains of many, and for a long time.

He was right, and in the next section we will explore a few examples of how it was almost another 100 years before the theory of New World degeneracy, which fed on the fears of a New World that might be competition for the Old World, disappeared.

\section{The debate over new world degeneracy outlives Buffon and Jefferson}

While the protagonists in the continued debate over New World degeneracy did not line up exactly as one might expect from continent of origins-Europeans for, Americans against-they came close, with a few very notable exceptions, like Prussian Alexander van Humboldt who dismissed degeneracy as "unphilosophical and contrary to generally acknowledged physical laws" (von Humboldt 1849).

Philosopher Georg Wilhelm Fredrich Hegel (17801831) was a vociferous advocate of the theory of degeneracy. Although he believed that the future might belong to America because of its youth, Hegel saw the current state of America as degenerate, as "the impotence of nature brings about...impure presentation..." (Hegel 1837).

References to New World inferiority pepper the work of poet John Keats (1795-1821). Degeneracy, with America as "the hated land", permeates a piece called Lines to Fanny (also called The Second Ode to Fannie Brawne):

\footnotetext{
${ }^{14}$ Daniel Webster's recollection of Jefferson, edited by Wiltse, Volume 1, pp. 376-377.
}

Where shall I learn to get my peace again?

To banish thoughts of that most hateful land...

That monstrous region, whose dull rivers pour

Ever from their sordid urns unto the shore...

Iced in the great lakes, to afflict mankind;

Whose rank-grown forests, frosted, black, and blind...

\section{There bad flowers have no scent, birds no sweet song,}

\section{And great unerring Nature once seems wrong.}

Darwin too had read Buffon's ideas on degeneracy. In a January 9, 1834 diary entry while on The Beagle, Darwin noted that "it is impossible to reflect on the changed state of the American continent without the deepest astonishment". What caused such deep astonishment? His explorations in South America had led him to believe that "Formerly it (South America) must have swarmed with great monsters: now we find mere pigmies (sic), compared with the antecedent, allied races". Darwin's thoughts turned to Natural History: "If Buffon had known of the gigantic sloth and armadillo-like animals, and of the lost Pachydermata, he might have said with a greater semblance of truth that the creative force in America had lost its power, rather than that it had never possessed great vigour".

Americans countered degeneracy in many ways, including in early school textbooks (Miller 1955). The most striking example of this is in the textbooks of the Reverend Jedidiah Morse (1761-1826), a well-respected historian and geographer of his day, and a contributor to the first encyclopedia published in the United States (Moss 1995).

The opening chapter of Morse's popular 1790 school textbook, The History of America in Two Books, is largely a refutation of the ideas of Buffon and de Pauw (Morse 1790). Chapter 1 of The History of America in Two Books quotes at length both Buffon and de Pauw, so students could see for themselves the sort of material that European philosophers were writing about their country. Morse told his young readers that even if climate was responsible for the traits that Buffon and De Pauw believed existed, they misapplied their own theory. Instead of degeneracy, from the "smaller size and less fierceness of its (America's) animals", Buffon and De Pauw should have deduced "the gentleness and sweetness of America's climate". At the end of Chapter 1, Morse 
explained that the theory of degeneracy was the product of the "ignorance or...studied forgetfulness of...the Old continent". Fifty years later, James Fenimore Cooper would echo Morse in a preamble debunking degeneracy: "Whereas the youth of this colony are found, by manifold experience", Cooper wrote in Satanstoe "to be not inferior in their natural geniuses to the youth of any other country in the world..." (Cooper and Fenimore 1845).

The response to degeneracy is evident in many genres of early American writing. One such genre was the satirical poem, many of which were political in nature. The "Hartford Wits", a group of Connecticut intellectuals, were well known for such poems. These satires would appear in newspapers and, above and beyond their political overtones, were a form of entertainment in the years following the American Revolution.

One of the more famous of the Hartford wits was Jefferson's friend, Joel Barlow, who upon reading Notes on the State of Virginia wrote to his colleague that he was overjoyed at "... the idea of seeing ourselves vindicated from those despicable aspirations which have long been thrown upon us and echoed from one ignorant scribbler to another in all languages of Europe."15

Barlow would use his biting wit to mock degeneracy in his poem called The Anarchiad (1787). In this poem, Buffon and de Pauw" are described as "...scan(ning) new worlds with philosophic eyes..." What they saw through their "philosophic eyes," is a land where:

... enfeebled powers of life decay

Where filling suns defraud the western day

Paint the dank, sterile globe, accurst by fate

Created, lost, or stolen from ocean late

For Barlow, these scans of America by the proponents of degeneracy were done through a bizarre philosophical telescope with "inverted optics:"

See vegetation, man, and bird, and beast,

Just by the distance squares in size decreased...

Huge mammoth dwindle to a mouse's size

Columbian turkeys turn European flies

Exotic birds, and foreign beasts, grow small
And man, the lordliest, shrink to least of all

While each vain whim their loaded skulls conceive

Whole realms shall reverence, and all fools believe...

There, with sure ken, th' inverted optics show

All nature lessening to the sage De Pau(w)

E'en now his head the cleric tonsures grace,

And all the abbe blossoms in his face;

His peerless pen shall raise, with magic lore

The long-lost pigmies on th' Atlantic shore...

The Anarchiad was not the only satirical poem that attacked degeneracy. David Humphreys, one of Barlow's friends, and a former aide-de-camp to General Washington during the Revolutionary War, used his popular play The Widow of Malabar" to the same effect (Humphreys 1804):

And let philosophers say what they please

You're not grown less by coming o'er the seas...

Your victories won-your revolution ended

Your constitution newly made and mended...

Will make the age of heroes, wits and sages

The first in the story to the latest ages!

\section{Gone at last}

Why the degeneracy theory vanished when it did in the mid 1850s is difficult to determine. Part of the reason may have been a sort of natural decay. By the 1850s, the key players were all long dead, and the loss of such dramatic personalities would naturally result in a loss of interest in what they were fighting about. More than that, it would have been obvious to almost all the players on the world stage that America was not degenerate. People moved more freely between Europe and America, and could see for themselves that what Buffon and de Pauw and others had said about humans degenerating in America was incorrect. In addition, the study of natural history had advanced significantly since the time of Buffon, and there was no evidence of American degeneracy 
(e.g., Wilson 1808). The economic facts, with America emerging as power player, also spoke against degeneracy.

In the face of all that, support for the theory of New World degeneracy diminished and then disappeared.

\section{Acknowledgements}

I thank Dana Dugatkin for proofreading this paper.

\section{Authors' contributions}

The author read and approved the final manuscript.

\section{Funding}

None

\section{Availability of data and materials}

No primary data was included in this review.

\section{Competing interests}

The author declares that they have no competing interests.

Received: 27 March 2019 Accepted: 31 May 2019

Published online: 06 June 2019

\section{References}

Adams J. A defence of the constitutions of Government of the United States of America. London: C. Dilly; 1787.

Beyerhaus G. Abbe de Pauw und Freierich der Grosse, eine Abrechnung mit Voltaire. Historische Zeitschrift. 1926;124:465-93.

Buffon GL. Historie naturelle. Imprimerie Royal, Paris; 1749-1788.

Church H. Corneille de Pauw and the controversy over his Recherches Philosophiques sur les Américains. PMLA. 1936;51:178-207.

Cooper J, Fenimore. Satonstoe. New York: Burgess, Stringer and Company; 1845
De Pauw C. Recherches philosophiques sur les Américains, ou Mémoires intéressants pour servir à l'Histoire de l'Espèce Humaine. Avec une Dissertation sur l'Amérique \& les Américains Berlin. 1768.

Dugatkin LA. Mr. Jefferson and the Giant Moose: natural history in early America. Chicago: University of Chicago Press; 2009.

Echeverría D. Mirage in the West. Princeton: Princeton University Press; 1957.

Gerbi A. The dispute of the New World: the history of a Polemic, 1750-1900. Pittsburgh: University of Pittsburgh Press; 1973.

Hegel GWF. Enzyklopadie der Philosphischen Wissenschaften. 1837.

Humphreys D. The miscellaneous works of David Humphrey. New York: Swords; 1804

Jefferson T. Notes on the State of Virginia. New York: Penguin Press; 1785

Miller R. American nationalism as a theory of nature. William Mary Q. 1955;12:74-95.

Morse J. The history of America in two books. Philadelphia: Thomas Dobson; 1790.

Moss R. The Life of Jedidiah Morse: a station of peculiar exposure. Knoxville: University of Tennessee Press; 1995.

Raynal A. Historie Philosphique et politique des establissements et du commerce des Europeens dans les deux Indes. 1772.

Roger J. Buffon: a life in natural history. Ithaca: Cornell University Press; 1997. von Humboldt A. Aspects of nature in different lands and different climates. Philadelphia: Lea and Blanchard; 1849.

Wilson A. American Ornithology; or, the Natural History of the Birds of the United States: Illustrated with Plates Engraved and Colored from Original drawings taken from Nature. 1808-1814.

Wiltse C, Moser H, editors. The papers of Daniel Webster. Correspondence, 1798-1824. Hanover: Dartmouth College/University Press of New England; 1974.

\section{Publisher's Note}

Springer Nature remains neutral with regard to jurisdictional claims in published maps and institutional affiliations.
Ready to submit your research? Choose BMC and benefit from:

- fast, convenient online submission

- thorough peer review by experienced researchers in your field

- rapid publication on acceptance

- support for research data, including large and complex data types

- gold Open Access which fosters wider collaboration and increased citations

- maximum visibility for your research: over $100 \mathrm{M}$ website views per year

At BMC, research is always in progress.

Learn more biomedcentral.com/submissions 